\title{
INTRAMURAL ESOPHAGEAL HEMATOMA AFTER ELECTIVE INJECTION SCLEROTHERAPY
}

\author{
Hannah Pitanga LUKASHOK ${ }^{1,2}$, Carlos ROBLES-MEDRANDA ${ }^{1,2}$, Marília de Andrade SANTANA ${ }^{1}$, \\ Marcia Henriques Magalhães COSTA ${ }^{1}$, Adriana de Almeida BORGES ${ }^{1}$, and Cyrla ZALTMAN ${ }^{1}$
}

\begin{abstract}
Context - Although endoscopic esophageal variceal sclerotherapy has been largely supplanted by variceal band ligation, it is still performed routinely in many institutions, especially in developing countries. Intramural esophageal hematoma has been described as a rare complication of sclerotherapy. Risk factors have not been completely established. Objective - To demonstrate the incidence of post-sclerotherapy intramural esophageal hematoma in our hospital and discuss the possible factors involved. Methods This is a retrospective observational study made at the "Hospital Universitário Clementino Fraga Filho", Rio de Janeiro, RJ, Brazil, reviewing the medical records of all esophageal variceal sclerotherapy procedures performed from April 2000 to November 2005. The evaluation of the clinical, laboratorial and endoscopic features in our patients and those reported in the literature was also done. Review of literature was performed through MEDLINE search. Results - A total of 1,433 esophageal variceal sclerotherapy procedures were performed in 397 patients, with an intramural esophageal hematoma incidence of 4 cases $(0.28 \%)$. Three of our patients developed additional complications, and one death was a direct consequence of a rupture of the hematoma. Nineteen well described cases were reported in the literature. Intramural esophageal hematoma occurred mostly after the forth esophageal variceal sclerotherapy session. Coagulation disturbances were present in the majority of cases. Conclusion - Intramural esophageal hematoma is a rare complication of esophageal variceal sclerotherapy and its incidence in our institution was similar to those observed in the literature. Our study suggests that this complication occurs as a result of a fragile esophageal mucosa after previous esophageal variceal sclerotherapy sessions. Impaired coagulation, although not essential, could contribute to hematoma formation and extension through esophageal submucosa.
\end{abstract}

HEADINGS - Esophageal diseases. Hematoma. Sclerotherapy.

\section{INTRODUCTION}

Endoscopic variceal sclerotherapy (EVS) remained the mainstay of variceal bleeding treatment for decades. Over the past 10 years, endoscopic band ligation, with its reduced rebleeding and complication rates, has largely supplanted sclerotherapy as the method of choice in acute and secondary prophylaxis ${ }^{(14,23)}$. However, EVS is still routinely performed in many institutions, especially in developing countries ${ }^{(9,20)}$, as it is less expensive and more widely available than banding. Recent data from the American College of Gastroenterology GI Bleeding Registry shows a still surprising utilisation of EVS in acute index bleeding $(36.8 \%)$, in rebleeding (30.4\%) and in elective secondary prophylaxis $(12.6 \%)^{(31)}$.

Intramural esophageal hematoma (IEH) is a rare condition in which an intramural hemorrhage leads to a varying degree of submucosal dissection of the esophageal wall ${ }^{(26)}$. It is a rare complication of sclerotherapy, with an incidence of $0.3 \%$ to $1.6 \% \%^{(7,}$ 18, 27). Until now, the risk factors associated with the development of this complication have not been completely established.

Our objective is to demonstrate the incidence of post-sclerotherapy esophageal hematoma in our hospital and to discuss possible factors involved, by the review of our cases and of those well documented from the literature.

\section{METHODS}

A retrospective observational study was performed at the "Hospital Universitário Clementino Fraga Filho" (HUCFF), Rio de Janeiro, RJ, Brazil, from April 2000 to November 2005, by reviewing the medical records of patients with a history of upper gastrointestinal bleeding from esophageal varices that

Gastroenterology Division, University Hospital "Clementino Fraga Filho", Federal University of Rio de Janeiro, Rio de Janeiro, Brazil; ' ${ }^{2}$ Hepatogastroenterology Department, Edouard Herriot Hospital, Lyon, France.

Correspondence: Dr. Hannah Pitanga Lukashok - Rua Moreira César, 282/603 I - Icaraí, 24230-063 - Niterói, RJ, Brasil. E-mail: hannah.pitanga@terra.com.br 
were in an EVS program for secondary prophylaxis. Patients who developed IEH as an EVS complication were evaluated in regard to clinical status (Child-Pugh class), coagulation profile: prothrombin time (PT) and platelets count (PC), endoscopic variables: number and intervals between EVS sessions, type of sclerosant agents (SA), concentration of SA, volume of SA, site of needle injection (intravasal, paravasal or combined) and variceal size.

An evaluation of the clinical, laboratorial and endoscopic features of the various EVS sessions in the same patient as well as in other patients reported in the literature was carried out.

The literature review was made through a MEDLINE (National Library of Medicine, Bethesda, MD, USA) search, using the terms "intramural, esophageal hematoma, sclerotherapy".

Only the cases well reported with regard to the clinical status, coagulation profile and endoscopic variables were analyzed for the purposes of our research.

\section{RESULTS}

During the referred-to period 1,433 EVS sessions were performed in 397 patients at HUCFF. The clinical diagnosis of the patients submitted to EVS sessions was: portal hypertension due to liver cirrhosis, schistosomiasis, portal vein thrombosis, Budd-Chiari syndrome and veno-occlusive disease.

Post-sclerotherapy IEH occurred in four patients (case 1, case 2 , case 3 , case 4 ), with an incidence of $0.28 \%$.

Case 1 was a 55-year-old man, with secondary billiary cirrhosis (Child B7) and an altered coagulation profile (PT $61 \%$ and $\left.\mathrm{PC} 42,000 / \mathrm{mm}^{3}\right)$. He developed a voluminous IEH after the $4^{\text {th }}$ EVS session.

Case 2 was a 74-year-old woman, with primary billiary cirrhosis (Child B7), submitted to eight ESV previous sessions. Three small esophageal varices recurred 1 year later, when one more EVS session was performed and complicated with a voluminous IEH causing total luminal obstruction.

Case 3 was a 50-year-old man, with alcoholic cirrhosis (Child A6), and an altered coagulation profile (PT 65\% and PC $\left.12,000 / \mathrm{mm}^{3}\right)$. After the second EVS session he presented a huge IEH, beginning at the base of the tongue and causing pharyngeal compression, without respiratory distress.

Case 4 was a 29 -year-old man with schistossomosis. He had a normal liver function and an altered coagulation profile (PT $80 \%$ and PC $76,000 / \mathrm{mm}^{3}$ ). After the $6^{\text {th }}$ EVS session he developed a $3 \mathrm{~cm}$ IEH with partial luminal obstruction.

Clinical symptoms began a few hours post-sclerotherapy (1-3 hours), except for P3, whose symptoms started 24 hours later. Symptoms for all four included severe retrosternal chest pain, dysphagia, odynophagia and hypersialorrheia.

All patients received clinical treatment with intravenous fluids, opioids for pain and proton pump inhibitors. Platelet and plasma transfusions were given to P1 and P3.

Esophageal symptoms disappeared in approximately one week, and upper endoscopy (UE) after 1 month showed complete hematoma resolution in $\mathrm{P} 1, \mathrm{P} 2$ and $\mathrm{P} 4$.
Complications of IEH were present in P2, P3 and P4. $\mathrm{P} 2$ presented a hemorrhagic pleural effusion secondary to an esophageal-pleural fistula, with worsening of the hepatic function. She was treated with IV antibiotics, and in 3 weeks pleural effusion had resolved and hepatic function improved. P3 presented, 2 days after IEH formation, massive hematemesis and broncoaspiration, soon after a UE to allow the placement of a gastric feeding tube under directed vision. He died in less than 24 hours. P4 developed dysphagia for solids due to an esophageal stenosis, after IEH resolution. Dysphagia was promptly resolved after esophageal dilatations sessions with Savary-Guillard bougies. Using the terms "intramural, esophageal hematoma, sclerotherapy", from 1982 to 2006, 20 articles reporting IEH cases post-sclerotherapy were found in the literature review made through a MEDLINE search.

Clinical, laboratorial and endoscopic variables of the patients in the referred-to sessions and in previous ones are shown in Table 1.

\section{DISCUSSION}

Endoscopic variceal ligation (EVL) has now replaced EVS in most centers of developed countries. Guidelines based on recent meta-analysis affirm that sclerotherapy should no longer be used in the secondary prophylaxis of variceal haemorrhage ${ }^{(8,13)}$. Data from randomized controlled trials shows that EVL produces more rapid variceal eradication with lower rates of recurrent bleeding and fewer complications such as strictures and perforation ${ }^{(19)}$. In addition, EVL is easier to perform, while EVS is a technique in which efficacy and safety are tied to the endoscopist's skill(5). However, in most studies, this does not result in an overall survival benefit relative to $\mathrm{EVS}^{(19)}$. Moreover, EVS carries a lower risk of variceal recurrence ${ }^{(2)}$, which could reduce the cost-benefit advantage of band ligation over EVS in the long term. This could be especially true in developing countries, where the costs of banding devices are extremely high.

Intramural esophageal hematoma is a rare complication of EVS, defined as a bulging dark-reddish submucosal mass leading to symptoms such as chest pain, dysphagia or hypersialohrrea which can occur just after, or until 48 hours after, EVS ${ }^{(10)}$. From April 2000 to November 2005, we reviewed 1,433 elective EVSs performed as secondary prophylaxis in 397 patients at the "Clementino Fraga Filho University Hospital". The frequency of IEH was $0.28 \%$ (four patients).

Nineteen well described cases were reported in the literature ${ }^{(1,3,4,6,7,10,12,22,24,25,29)}$. Eleven were males. The ages varied from 35 to 76 (mean $54 \pm 12$ ). The etiology of cirrhosis was alcoholic in 12 , primary biliary in 2, viral hepatitis $\mathrm{C}$ in 2 , nodular regenerative hyperplasia in 1 and cryptogenic in 1 patient. Prothrombine time varied from $55 \%$ to $100 \%$ and platelet count varied from 50,000 to $121,000 \mathrm{~mm}^{3}$. Sclerosant agents used included ethanolamine $5 \%$, polidocanol $1 \%$ to $2 \%$ and sodium tetradecyl sulfate $1.5 \%$ to $3 \%$. One patient developed a pleural effusion ${ }^{(22)}$, one had rupture of a hematoma without clinical consequences ${ }^{(17)}$ and two presented a tracheal compression with respiratory insufficiency ${ }^{(1,3)}$. All cases 
TABLE 1. Endoscopic features in the EVS sessions complicated by IEH

\begin{tabular}{|c|c|c|c|c|c|c|}
\hline & Session & Varices size & Injection site & Sclerosant $(\%)$ & Volume & Interval \\
\hline \multicolumn{7}{|l|}{ Our cases: } \\
\hline Case 1 & $4^{\text {th }}$ & medium & I & $\mathrm{E}(2.5 \%)$ & $24 \mathrm{~mL}$ & 3 weeks \\
\hline Case 2 & $9^{\text {th }}$ & small & I & $\mathrm{E}(2.5 \%)$ & $11 \mathrm{~mL}$ & 1 year \\
\hline Case 3 & $2^{\text {nd }}$ & medium & I & $\mathrm{E}(2.5 \%)$ & $20 \mathrm{~mL}$ & 1 week \\
\hline Case 4 & $6^{\text {th }}$ & small & I & $\mathrm{E}(2.5 \%)$ & $33 \mathrm{~mL}$ & 2 weeks \\
\hline Mosimann $^{(27)}$ & $5^{\text {th }}$ & $?$ & $\mathrm{I} / \mathrm{P}$ & Po $(1 \%)$ & $?$ & $?$ \\
\hline $\operatorname{Chen}^{(7)}$ & $15^{\text {th }}$ & small & I & $\operatorname{STD}(3 \%)$ & $1 \mathrm{~mL}$ & ? \\
\hline \multicolumn{7}{|l|}{ Desmorat $^{(10)}$ : } \\
\hline Case 1 & $5^{\text {th }}$ & $?$ & $\mathrm{I} / \mathrm{P}$ & $\operatorname{Po}(1 \%)$ & $60 \mathrm{~mL}$ & 4 weeks \\
\hline Case 2 & $4^{\text {th }}$ & medium & $\mathrm{I} / \mathrm{P}$ & Po $(1 \%)$ & $47 \mathrm{~mL}$ & 5 weeks \\
\hline Case 3 & $6^{\text {th }}$ & small & $\mathrm{I} / \mathrm{P}$ & Po $(1 \%)$ & $25 \mathrm{~mL}$ & 24 weeks \\
\hline $\operatorname{Low}^{(24)}$ & $2^{\text {nd }}$ & medium & $\mathrm{I} / \mathrm{P}$ & STD $(1.5 \%)$ & $9 \mathrm{~mL}$ & 4 days \\
\hline $\mathrm{Li}^{(22)}$ & $5^{\text {th }}$ & medium & $\mathrm{I} / \mathrm{P}$ & Po (?) & $27 \mathrm{~mL}$ & 2 weeks \\
\hline Jones ${ }^{(17)}$ & $2^{\text {nd }}$ & $?$ & I & $\mathrm{E}(5 \%)$ & $4.5 \mathrm{~mL}$ & 6 weeks \\
\hline Benoit $^{(4)}$ & $4^{\text {th }}$ & $?$ & $?$ & Po $(1 \%)$ & $9 \mathrm{~mL}$ & $?$ \\
\hline \multicolumn{7}{|l|}{ Beljon $^{(3)}$ : } \\
\hline Case 1 & $5^{\text {th }}$ & large & $\mathrm{I} / \mathrm{P}$ & E $(5 \%)$ & $11 \mathrm{~mL}$ & 1 week \\
\hline Case 2 & $4^{\text {th }}$ & medium & I & $\mathrm{E}(5 \%)$ & $5 \mathrm{~mL}$ & 1 week \\
\hline Case 3 & $11^{\text {th }}$ & large & $\mathrm{I} / \mathrm{P}$ & $\mathrm{E}(5 \%)$ & $2 \mathrm{~mL}$ & 1 week \\
\hline Case 4 & $7^{\text {th }}$ & large & I & E $(5 \%)$ & $15 \mathrm{~mL}$ & 1 week \\
\hline \multicolumn{7}{|l|}{ Salomez ${ }^{(29)}$ : } \\
\hline Case 1 & $4^{\text {th }}$ & $?$ & $\mathrm{I} / \mathrm{P}$ & Po $(1 \%)$ & $20-40 \mathrm{~mL}$ & 3 weeks \\
\hline Case 2 & $6^{\text {th }}$ & medium & $\mathrm{I} / \mathrm{P}$ & Po $(1 \%)$ & $20-40 \mathrm{~mL}$ & 4 weeks \\
\hline Brosolo $^{(6)}$ & $2^{\text {nd }}$ & medium & $\mathrm{I} / \mathrm{P}$ & $\operatorname{Po}(1.5 \%)$ & $14 \mathrm{~mL}$ & 3 weeks \\
\hline Meier ${ }^{(25)}$ & $5^{\text {th }}$ & medium & $\mathrm{I} / \mathrm{P}$ & STD $(3 \%)$ & $4 \mathrm{~mL}$ & 4 weeks \\
\hline Adachi $^{(1)}$ & $4^{\text {th }}$ & no varice & $\mathrm{P}$ & Po (?) & $?$ & 1 week \\
\hline Favre $^{(12)}$ & $4^{\text {th }}$ & medium & $?$ & Po $(2 \%)$ & $25 \mathrm{~mL}$ & 3 weeks \\
\hline
\end{tabular}

$=$ intravasal; $\mathrm{P}=$ paravasal; $\mathrm{E}=$ ethanolamine; $\mathrm{mL}=$ milliliters;

Po = polidocanol; STD = sodium tetradecyl sulfate; ? = not reported

were managed conservatively, except those complicated by tracheal compression, the treatment of which consisted of an endoscopic incision of the hematoma in one ${ }^{(1)}$ and a tracheal intubation in the other ${ }^{(3)}$. No deaths were reported.

In our case series, three of our four patients developed additional complications, and one death was a direct consequence of a rupture of the hematoma. Of these three, one developed a hemorrhagic pleural effusion due to a small esophageal fistula, another presented an esophageal stenosis after resolution of the hematoma, and the third died 24 hours after a feeding tube placement under direct endoscopic vision. Although there is no formal contra-indication to endoscopy or enteral feeding in the presence of IEH, this incident corroborates the recommendation of some authors to avoid endoscopy even as a diagnostic tool ${ }^{(27)}$. Moreover, IEH generally is resolved in less than 7 days of conservative treatment (intra-venous fluids, proton pomp inhibitors and correction of coagulation defects), which precludes the need of enteral or parenteral nutrition. Although a few authors have used antibiotics as part of the conservative management of $\operatorname{IEH}^{(6,29)}$, there is no scientific basis to support its use, and we recommend it only when it is associated with fever or other complications (eg. in cases with esophageal-pulmonary fistula).

The endoscopic features of the above cases are shown in Table 1 .
Due to the rarity of IEH as a complication of EVS, there is no prospective, controlled study analyzing the risk factors to the development of IEH. However, this review of our cases and of those reported in the literature leads us to interesting observations. IEH occurs post EVS without regard to variceal size, sclerosant agent, its concentration and volume, or interval between sessions, suggesting that those factors do not influence IEH formation. DESMORAT et al. ${ }^{(10)}$ suggested that intravariceal injection could be the trigger of IEH ${ }^{[15]}$. However, it was demonstrated that nearly $50 \%$ of all attempted intravasal injections result in paravasal accumulation of the injected material ${ }^{(15)}$ which makes, the analysis of the different injection techniques (intravasal, paravasal and combined) as a risk factor for IEH difficult. Moreover, IEH has been described as occurring after EVS independently of the injection technique.

Altered prothrombin time and a low platelet count were present in most cases. Only two patients had PC below 50,000, which is the proposed threshold limit for invasive procedures in the absence of platelet dysfunction ${ }^{(30)}$. However, it is well known that cirrhotic patients do have platelet dysfunction with reduced platelet aggregation ${ }^{(21)}$ and adhesion defects that can already be present in mild liver failure ${ }^{(28)}$. This could be a possible mechanism that favors IEH formation and extension in patients with acceptable PC counts. 
An interesting observation - that corroborates the role of an altered structure of the esophageal wall as a risk factor - was that IEH was not observed either in our cases or in the reviewed literature, as occurring after the first EVS session. It usually occurs after the fourth one. Furthermore, the patients in our series had similar clinical and laboratorial features in all EVS sessions, suggesting that the more manipulated the esophageal wall is - due to previous sclerosant injections - the greater the risk of IEH development.

In conclusion, EVS is still widely used for variceal eradication, especially in developing countries, and IEH should be regarded as a rare complication that carries a good prognosis with conservative management. Although we cannot establish a causal relationship between variables due to the limitations of this observational study, we suggest that IEH occurs in patients who have undergone prior EVS sessions and that impaired coagulation could contribute to hematoma formation and extension through esophageal submucosa.

\section{ACKNOWLEDGEMENTS}

The authors are indebted to David E. Lukashok, MA, Mônica Soldan, MD, Jerôme Dumortier, MD, PhD. and Rene Lambert, MD, PhD.

Lukashok HP, Robles-Medranda C, Santana MA, Costa MHM, Borges AA, Zaltman C. Hematoma intramural esofágico após escleroterapia eletiva de varizes. Arq Gastroenterol. 2009;46(4):279-83.

RESUMO - Contexto - Apesar do fato de que a escleroterapia endoscópica de varizes esofágicas vem sendo largamente substituída pela técnica de ligadura elástica, a escleroterapia é ainda rotineiramente utilizada em muitas instituições, especialmente em países em desenvolvimento. O hematoma intramural esofágico é uma complicação rara da escleroterapia e os fatores de risco para seu desenvolvimento ainda não estão completamente estabelecidos. Objetivo - Demonstrar a incidência do hematoma intramural esofágico pós-escleroterapia no Hospital Universitário Clementino Fraga Filho, Rio de Janeiro, RJ, e discutir os possíveis fatores envolvidos. Métodos - Este é um estudo retrospectivo observacional realizado no Hospital Universitário Clementino Fraga Filho, através da revisão dos prontuários médicos de todos os pacientes submetidos a escleroterapia endoscópica de varizes esofágicas entre abril de 2000 e novembro de 2005. Uma avaliação das características clínicas, laboratoriais e endoscópicas desses pacientes e dos descritos na literatura foi realizada. A revisão da literatura foi feita através de pesquisa no MEDLINE. Resultados - Foram realizados 1.433 procedimentos de escleroterapia endoscópica de varizes esofágicas em 397 pacientes, com incidência de hematoma intramural esofágico de 4 casos (0,28\%). Três dos quatro pacientes desenvolveram complicações adicionais e um falecimento foi consequência direta do hematoma intramural esofágico. Dezenove casos bem documentados de hematoma intramural esofágico foram descritos na literatura. Na maioria dos casos o hematoma intramural esofágico ocorreu a partir da quarta sessão de escleroterapia endoscópica de varizes esofágicas e distúrbios de coagulação estavam presentes. Conclusão O hematoma intramural esofágico é complicação rara da escleroterapia e a incidência no hospital onde foi realizada esta pesquisa foi similar à observada na literatura. Este estudo sugere que essa complicação resulta de mucosa fragilizada por sessões previa de escleroterapia endoscópica de varizes esofágicas. Distúrbios da coagulação, apesar de não serem essenciais, podem contribuir para a formação e extensão do hematoma através da submucosa esofágica.

DESCRITORES - Esofagopatias. Hematoma. Escleroterapia.

\section{REFERENCES}

1. Adachi T, Togashi H, Watanabe H, Okumoto K, Hattori E, Takeda T, Terui Y, Aoki M, Ito J, Sugahara K, Saito K, Saito T, Kawata S. Endoscopic incision for esophageal intramural hematoma after injection sclerotherapy: case report. Gastrointest Endosc. 2003;58:466-8.

2. Baroncini D, Milandri GL, Borioni D, Piemontese A, Cennamo V, Billi P, Dal Monte PP, D'Imperio N. A prospective randomized trial of sclerotherapy versus ligation in the elective treatment of bleeding esophageal varices. Endoscopy. 1997;29:235-40.

3. Beljon JV, Krige J, Bornman PC. Intramural esophageal hematoma after endoscopic injection sclerotherapy for bleeding varices. Dig Endosc. 2004;16:61-5.

4. Benoit R, Legoux JL, Serve MP, Khadre K, Festin D, Causse X. Hématome intra-mural obstructif de l'oesophage post-sclérothérapie. Presse Med. 1996;25:1281-4.Boix J, Lorenzo-Zúñiga V, Moreno de Vega V, Domènech E, Gassull MA. Sclerotherapy and esophageal variceal bleeding: time to forget it, or not? Endoscopy. 2007;39:478.

5. Brosolo P, Maieron R, Da Broi GL. A post-sclerotherapy complication: intramural hematoma of the esophagus. Endoscopy. 1993;25:431.

6. Chen TA, Lo GH, Lai KH. Spontaneous rupture of iatrogenic intramural hematoma of esophagus during endoscopic sclerotherapy. Gastrointest Endosc. 1999;59:850-1.

7. de Franchis R, Primignani M. Endoscopic treatments for portal hypertension. Semin Liver Dis. 1999;19:439-55.

8. de Paulo GA, Ardengh JC, Nakao FS, Ferrari AP. Treatment of esophageal varices: a randomized controlled trial comparing endoscopic sclerotherapy and
EUS-guided sclerotherapy of esophageal collateral veins. Gastrointest Endosc. 2006;63:396-402

9. Desmorat H, Cales P, Vinel JP, Maquin P, Caucanas JP, Combis JM, Pascal JP. Hématome intramural obstructif de l'oesophage: une complication rare de la sclérose endoscopique des varices esophagiennes. Gastroenterol Clin Biol. 1990;14:581-5.

10. Evans DM, Jones DB, Cleary BK, Smith PM. Oesophageal varices treated by sclerotherapy: a histopatological study. Gut 1982;23:615-20.

11. Favre O, Genin G, Souquet JC. Une complication inhabituelle de la sclerotherapie de varices oesophagiennes: l'hematome obstructif de l'oesophage. Gastroenterol Clin Biol. 1990;14:100-1.

12. Garcia-Tsao G, Sanyal AJ, Grace ND, Carey WD; Practice Guidelines Committee of American Association for Study of Liver Diseases; Practice Parameters Committee of American College of Gastroenterology. Prevention and management of gastroesophageal varices and variceal hemorrhage in cirrhosis. Am J Gastroenterol. 2007;102:2086-102.

13. Gimson AE, Ramage JK, Panos MZ, Hayllar K, Harrison PM, Williams R, Westaby D. Randomised trial of variceal banding ligation versus injection sclerotherapy for bleeding esophageal varices. Lancet. 1993;342:391-4.

14. Grobe JL, Kozarek RA, Sanowski RA, LeGrand J, Kovac A. Venography during endoscopic injection sclerotherapy of esophageal varices. Gastrointest Endosc. 1984;30:6-8.

15. Helpap B, Bollweg L. Morphologic changes in the terminal oesophagus with varices, following sclerosis of the wall. Endoscopy. 1981;13:229-33.

16. Jones DB, Frost RA, Goodacre RL. Intramural hematoma of the esophagus. A complication of endoscopic injection sclerotherapy. Gastrointest Endosc. 1986;32:239-40. 
17. Kahn D, Jones B, Bornman PC, Terblanche J. Incidence and management of complications after injection sclerotherapy: a ten-year prospective evaluation. Surgery. 1989;105:160-5.

18. Krige JE, Shaw JM, Bornman PC. The evolving role of endoscopic treatment for bleeding esophageal varices. World J Surg. 2005;29:966-73.

19. Krige JE, Kotze UK, Bornman PC, Shaw JM, Klipin M. Variceal recurrence, rebleeding, and survival after endoscopic injection sclerotherapy in 287 alcoholic cirrhotic patients with bleeding esophageal varices. Ann Surg. 2006;244: 764-70.

20. Laffi G, Marra F, Gresele P, Romagnoli P, Palermo A, Bartolini O, Simoni A, Orlandi L, Selli ML, Nenci GG, et al. Evidence for a storage pool defect in platelets from cirrhotic patients with defective aggregation. Gastroenterology. 1992;103:641-6.

21. Li V, Zarski JP, Boulard JC, Fricamps-Pironi C, Rachail M. Une complication rare de la sclerose des varices oesophagiennes: l'hematome intramural pharyngooesophagien. Gastroenterol Clin Biol. 1990;14:101-2.

22. Lo GH, Lai KH, Cheng JS, Hwu JH, Chang CF, Chen SM, Chiang HT. A prospective, randomized trial of sclerotherapy versus ligation in the management of bleeding esophageal varices. Hepatology. 1995;22:466-71.

23. Low DE, Patterson DJ. Complete esophageal obstruction secondary to dissecting intramural hematoma after endoscopic sclerotherapy. Am J Gastroenterol $1988 ; 83: 435-8$
24. Meier JH, Zeitlin JH, Smith MT. Post-sclerotherapy intramural esophageal hematoma: endoscopic and radiologic findings. Gastrointest Endosc. 1992;38:102-3.

25. Meulman N, Evans J, Watson A. Spontaneous intramural haematoma of the oesophagus: a report of three cases and review of the literature. Aust N Z J Surg. 1994;64:190-3.

26. Mosimann F, Brönnimann B. Intramural haematoma of the oesophagus complicating sclerotherapy of varices. Gut 1994;35:130-1.

27. Ordinas A, Escolar G, Cirera I, Viñas M, Cobo F, Bosch J, Terés J, Rodés J. Existence of a platelet-adhesion defect in patients with cirrhosis independent of the hematocrit: studies under flow conditions. Hepatology. 1996;24:1137-42.

28. Salomez D, Ponette E, Van Steenbergen W. Intramural hematoma of the esophagus after variceal sclerotherapy. Endoscopy. 1991;23:299-301.

29. Samama CM, Djoudi R, Lecompte T, Nathan-Denizot N, Schved JF; Agence Française de Sécurité Sanitaire des Produits de Santé expert group. Perioperative platelet transfusion: recommendations of the Agence Française de Sécurite Sanitaire des Produits de Santé (AFSSaPS) 2003. Can J Anaesth. 2005;52:30-7.

30. Sorbi D, Gostout CJ, Peura D, Johnson D, Lanza F, Foutch PG, Schleck CD, Zinsmeister AR. An assessment of the management of acute bleeding varices: a multicenter prospective member-based study. Am J Gastroenterol. 2003;98:2424-34.

Recebido em 24/11/2008 Aprovado em 23/3/2009. 